九州大学学術情報リポジトリ

Kyushu University Institutional Repository

Studies on the hippolytid shrimps from Japan, I. : Revision of the Japanese species of the genus Eualus, with description of two new species

Miyake, Sadayoshi

Zoological Laboratory, Department of Agriculture, Kyushu University

Hayashi, Ken-Ichi

Zoological Laboratory, Department of Agriculture, Kyushu University

https://doi.org/10.5109/22759

出版情報: 九州大学大学院農学研究院紀要. 14 (2)，pp.247-265，1967-03. Kyushu University バージョン：

権利関係 : 


\section{Studies on the hippolytid shrimps from Japan, I. Revision of the Japanese species of the genus Eualus, with description of two new species ${ }^{1,2}$}

\section{Sadayoshi Miyake and Ken-Ichi Hayashi}

In spite of the abundance of the species belonging to the family Hippolytidae in shallow waters, there is little information on their faunal works from the taxonomical aspect in Japan. We will attempt to reveal and revise the hippolytid fauna of Japan and its adjacent seas in the scrics of this study.

The first report deals with the species belonging to the genus Eualus which has been establised by Thallwitz in 1892. The generic name, however, has not been adopted by many other authors, except for the Russian authors, and this genus has been included in the large genus Spirontocaris Bate. Holthuis (1947) divided this Spirontocaris s. 1. into six genera, by the presence or absence of the spines on the carapace and of the exopod on the third maxilliped. We follow his classification in this study. The genus Eualus is characterized by having a mandibular palp of two segments, an exopod on the third maxilliped and no supraorbital spinc.

The five species of the genus Eualus have been reported from Japanese seas, e.g. E. biunguis (Rathbun), E. gracilirostris (Stimpson), E. leptognathus (Stimpson), E. middendorffi (Brashnikov) and E. fabricii ( $\mathrm{Kr} \phi$ yer), the last one of them is not available. In addition to these four species, E. kuratai and E. kikuchii, so far as we know, are new to the science. The material used in this paper is deposited at the Zoological Laboratory, Faculty of Agriculture, Kyushu University (ZLKU).

We wish to express our hearty thanks to Dr. Hiroshi Kurata of the Tokai Regional Fisheries Research Laboratory and to Dr. Taiji Kikuchi of the Amakusa Marine Biological Laboratory, for kindness to offer us the specimens upon which this paper is based.

1) Contributions from the Zoological Laboratory, Faculty of Agriculture, Kyushu University, No. 356.

2) Contributions from the Amakusa Marine Biological Laboratory, Kyushu University, No. 198. 
Key to the species of the genus Eualus from Japan.

1 All pereiopods without epipods. Antepenultimate segment of antennular peduncle without spine on anterior margin near dorsal side....

An epipod at least present on first two pereiopods.

Three segments of antennular peduncle with a spine on anterior margin near dorsal side

2 Third maxilliped with epipod. Dactyli of last three pereiopods each with a long subterminal spinule. Eye large pyriform.......................... biunguis (Rathbun)

Third maxilliped without epipod. Dactyli of last three pereiopod normal. Eye small or moderate.

3 Fourth and fifth abdominal somites each with middorsal spine on posterior margin. Size large (41 and $65 \mathrm{~mm}$ in ovigerous female) ...E. middendorffi (Brashnikov)

Fourth and fifth abdominal somites without middorsal spine on posterior margin. Size small (30 $\mathrm{mm}$ in ovigerous female)

E. kuratai sp. nov.

4 First two pairs of pereiopods with epipods...E. gracilirostris (Stimpson)

First three pairs of pereiopods with epipods

5 Rostrum equal to or longer than carapace with four teeth on upper border and three or four on distal half of lower border. Pleuron of fifth abdominal somite pointed posteriorly ......E. leptognathus (Stimpson)

Rostrum about half length of carapace with five teeth on upper and one (or no) on lower border near apex. Pleura of both fourth and fifth abdominal somites pointed posteriorly

E. kikuchii sp. nov.

\section{Description of species \\ Eualus biunguis (Rathbun, 1902)}

(Fig. 1, a, b)

Spirontocaris biunguis Rathbun, 1902, 899-Off Cape St. James, Queen Charlotte Islands, British Columbia, $876 \mathrm{fms}$. (Type locality); Bering Sea to Oregon, 109 to $987 \mathrm{fms}$.

Spirontocaris biunguis: Rathbun, 1904, 97-Bering Sea to Oregon.

Spirontocaris biunguis: Yokoya, 1933, 27, fig. 9, A-C-Sea of Japan ; YamatoRidge, $620 \mathrm{~m}$, North of Sado Is., $454 \mathrm{~m}$.

Eualus biunguis : Derjugin \& Kobjakowa, 1935, 142-Continental side of Sea of Japan.

Eualus biunguis: Holthuis, 1947, 10-No locality. 


\section{Material examined:}

Off Muroran, Hokkaido, $330 \mathrm{~m}$ deep, 1 ovig. 우, 1 우, ZLKU No. 2412, June 20, 1962, K. Hayashi leg.

Description: The species is large, measuring about $70 \mathrm{~mm}$ in body length. The rostrum is laterally compressed and longer than the carapacc; there is a well-developed lateral ridge which extends from the upper border of the orbit to the foremost tooth of the lower border; six teeth are present on the proximal half of the upper border, of which the posterior two lie on the carapace; the lower part of the rostrum below the lateral ridge is expanded, being deeper than the upper part, and provided with five (in ovigerous female) and seven (in female) teeth; the distal part of the rostrum is slender and cylindrical, and toothless on both upper and lower borders. The antennal spine is well developed and separated from the low suborbital lobe, and the pterygostomian anglc is a spiniform process.

The eye is large and pyriform; the cornea covers the base of the eyestalk on the inner side.

The antennular peduncle extends to the foremost tooth on the upper border of the rostrum; the stylocerite is broad, reaching the distal tip of the basal scgment of the antennular peduncle; the second and third segments are provided with a small spine at the anterior part of the dorsal side.

The antennal scale is large, exceeding beyond the distal tip of the antennular peduncle; the outer margin is straight and ends in a strong spine, falling short of the lamellar part.

The mandibular palp is two-jointed, and the incisor process bears some irregular teeth along the apex.

The third maxilliped is provided with both of the exoped and the epipod. The first pereiopod slightly extends to the basal antennular peduncle; the chela is longer than the carpus. The second pereiopod is long and slender, extending to the lamellar part of the antennal scale by the small chela.

The following three pereiopods are long, slender and subequal in length, all extending to the rostral apex; there are four or five (rarely seven) teeth on the lateral side of each merus of the third, fourth and fifth
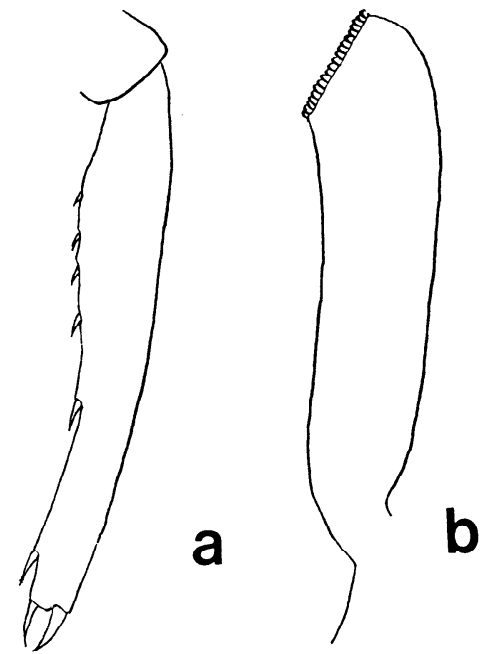

Fig. 1. Eualus biunguis (Rathbun).

a, Dactylus of third pereiopod ; $\mathrm{b}$, appendix interna in female. 
pereiopods; the dactylus of each pereiopod is provided with several minute spinules on the ventral side, of which the distal one is developed and situated against the terminal claw, giving the appearance of a minute chela (Fig. 1, a).

The third abdominal somite is prominent measuring two times as long as the second one dorsally; the ending is produced obtusely. The pleuron of the fifth somite is pointed posteriorly. The telson is long, measuring one and a fourth times as long as the sixth somite, and provided with five pairs of minute spines on the dorsal side near the lateral margin, and with three pairs of spines at the apex. The endopod of the uropod is longer than the telson including the terminal spines, and shorter than the exopod of the uropod.

The appendix interna in female is comparatively broad, measuring a quarter of its length, and bears many minute coupling hoods along the inner tip (Fig. 1, b).

Remarks: This species is recorded from the west coast of North America, Bering Sea to Oregon, at the depth of 109-987 fms. [ca. 200-1800 $\mathrm{m}]$ and from north of Sea of Japan at the depth of 454-620 m. The species is distinguished from the others by the subchelate dactyli of the last three pereiopods and the large pyriform eye.

\section{Eualus middendorffi Brashnikov, 1907}

(Fig. 2, a-c)

Eualus middendorffi Brashnikov, 1907, 165, fig. 23, a-b -Sakhalin; Kaibato Is., 56 r.s. deep, Taraika Bay, 15-20 r. s., East coast of Naka-Shiritoko Pen., 43 r.s., Aniwa Bay 16 r.s. (not read).

Spirontocaris middendorff: Balss, 1914, 45-Kasutori Bay.

Eualus middendorffi: Derjugin \& Kobjakowa, 1935, 142-Continental side of Sea of Japan.

Spirontocaris middendorffi; Urita, 1942, 21, fig. 5-Sakhalin; Otomari, 16 fms., Uryu, ca. 25 fms., Maoka, ca. 15 fms.

Eualus middendorff; Holthuis, 1947, 10- No locality.

Spirontocaris middendorff; Miyake, Sakai \& Nishikawa, 1962, 123-Off Tottori Pref.

Material examined:

Off Ajiro, Tottori Pref., $300 \mathrm{~m}$ deep, 1 o, 1 ovig. ㅇ. ZLKU No. 2286, Sept. 2, 1961, Tottori Prefectural Fisheries Experimental Station leg.

Off Nishi-Shimamaki, Hokkaido, $130 \mathrm{~m}$ deep, 1 ovig. 우, 1 우, ZLKU No. 2414, July 3, 1959, M. Yoshida leg.

Ten miles off north-west of Monbetsu, Hokkaido faced to the Sea of Okhotsk, 70-90 m deep, 1ㅅ․ ZLKU No. 2423, Oct. 22, 1959, collector 
unknown.

Off Yoichi, Ishikari Bay, Hokkaido, $70 \mathrm{~m}$ deep, 1 ㅇ, ZLKU No. 2425, collected by a gill net of the plaice-fishing, Feb. 21, 1956, collector unknown.

Description: This species is rather smaller than the former species, measuring 41 and $65 \mathrm{~mm}$ in body length in ovigerous female. The rostrum is straight, slender, with a low lateral ridge, and longer than the carapace; there are four teeth on the upper proximal half of the rostrum, of which the hindmost one is setting on the carapace, and the distal half of the upper border is toothless; the lower border is provided with seven teeth, of which the foremost one is small, and situated near the rostral apex. The antennal spine is acute and separated by a notch from a blunt suborbital lobe, and the pterygostomian spine is small but distinct.

The eye is moderate; the cornea is slightly shorter than the stalk.

The antennular peduncle reaches as far as the proximal third of the antennal scale; the second and third segments are provided with a small spine at the distal part of the dorsal side; the stylocerite reaches to the distal tip of the basal segment of the antennular peduncle. The antennal scale is large, four and a half times as long as wide, reaching forward the rostral apex; the outer margin is straight or a little concave; the apex ends in a strong spine, falling short of the lamellar part. The mandibular palp is composed of two joints and the incisor process bears eight teeth. The third maxilliped is provided with a long exopod, without an epipod; the ultimate segment is about three times as long as the penultimate segment.

The first pereiopod slightly extends to the antennular peduncle. The second pereiopod is long, slender and reaches to the tip of the outer antennular flagellum; the carpus is long and subdivided into seven joints. The following three pereiopods are long and slender; the third one reaches forward nearly as far as the distal tip of the lamellar part of the antennal scale; there are threc or four spines on the lateral side of the merus; the propodus is two or more times as long as the carpus, and provided with short ten spinules on the ventral side; the dactylus is provided with seven spinules on the ventral side including the terminal claw. The fourth pereiopod is slightly falling short of the outer spine of the antennal scale. The fifth pereiopod reaches about to the middle of the antennal scale.

Each of the third to fifth abdominal somites bears a diagnostic spine at the middle of the posterior margin in both sexes, and moreover, the third somite has one additional sharp spine at the subterminal part in the male specimen from Hokkaido (Fig. 2, a), but the larger male from Tottori Pref. has not such a subterminal spine. The pleuron of the fifth 
somite is posteriorly pointed. The telson is as long as or slightly longer than the sixth somite, and provided with four pairs (or asymmetrically five on one side) of spines on the dorsal side. The exopod and endopod of the uropod are longer than the telson including the terminal spines in female, but the endopod is slightly shorter than the telson in male.
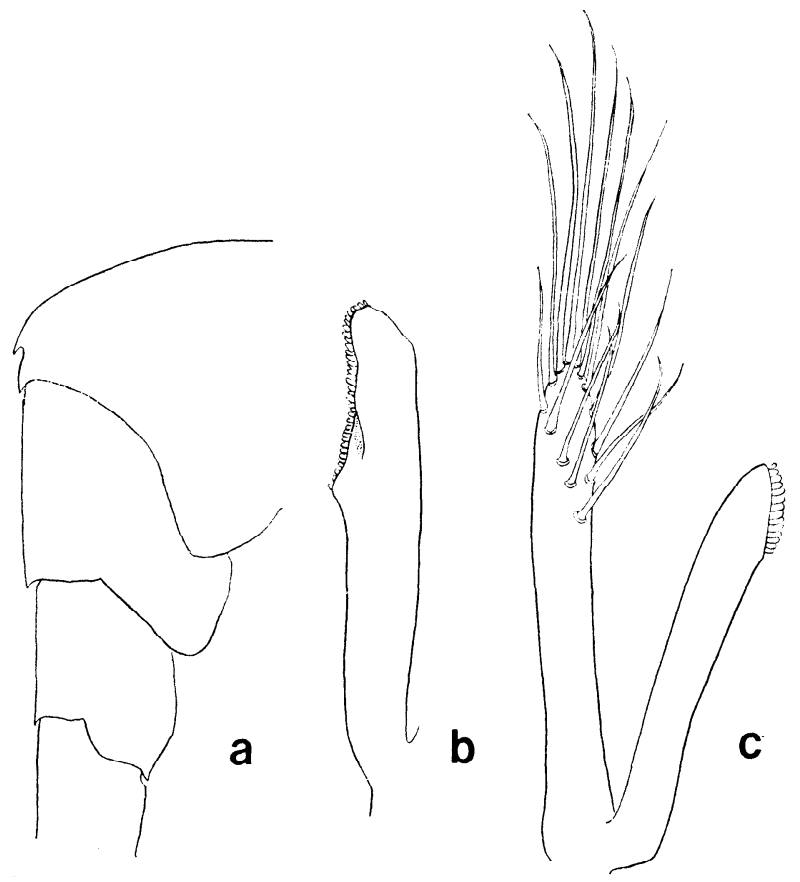

Fig. 2. Eualus middendorff Brashnikov.

a, Third to sixth abdominal somites of the specimen from Hokkaido;

$b$, appendix interna in female ; $c$, appendix interna and appendix masculina in male.

The appendix interna in ovigerous female is long, about five times as long as broad, bearing small coupling hooks along the distal two-fifths of the inner margin (Fig. 2, b). The appendix masculina in the larger male is as large as and longer than the appendix interna and bears fourteen long hairs near the apex (Fig. 2, c).

Colour: Urita (1942) gives the following note concerning the colouration of the present species: "Reddish vermilion, telson and uropods vermilion."

Remarks: The species has been recorded from the Sea of Okhotsk, Bering Sea, and Sakhalin to Sea of Japan. In our material four specimens werc collected from Hokkaido at the depth of 70-130 m, and 
two specimens were from as far south as off Tottori Pref. (ca. $35^{\circ} 40^{\prime} \mathrm{N}$ ) at the depth of $300 \mathrm{~m}$.

The male specimen has a diagnostic subterminal spine on the third abdominal somite in the original and the succeeding some literature (Balss, 1914; Urita, 1942), and indeed, the smaller male from Hokkaido has the conspicuous subterminal spine but the larger one from Tottori Pref. has no such spine. This fact, shows an affinity to the Atlantic species, E. gaimardi H. Milne Edwards, as to the gibbosity of the third somite (Holthuis, 1947). In this species, however, the terminal spines of the third to fifth abdominal somites are present in both sexes and do not show distinctive differences in strength between northern and southern forms in Japan.

\section{Eualus kuratai sp. nov.}

(Fig. 3, a-d)

Holotype: Between Rishiri I. and Rebun I., Hokkaido, 100-150 m deep, 1 ovig. +, ZLKU No. 2419, Jan. 15, 1957, T. Fukuda leg.

Paratypes: Data as for the holotype, 3 ovig. 우우, ZLKU No. 2420.

Description of holotype: The species is very closely related to the preceding, $E$. middendorff, in general body form, but much smaller, measuring about $30 \mathrm{~mm}$ in body length. The rostrum is slender with a low lateral ridge; the upper border is armed with four teeth on the proximal half, the first of which stands on the carapace. The lower border bears five teeth. The carapace is shorter than the rostrum; a well-developed antennal spine is also present on the antero-lateral anglc of the carapace (Fig. 3, a).

The eye is rather large; the proportional length of the stalk to the cornea in this species is longer than that of E. middendorffi.

The antennular peduncle extends to the middle point of the rostrum; the stylocerite reaches almost to the end of the ultimate segment of the antennular peduncle. The antennal scale is long, extending to the rostral apex by the inner angle of the lamellar tip; the scale is equal in breadth at both of the proximal and distal parts.

The third maxilliped reaches well beyond the tip of the antennular peduncle; the exopod is well developed. The first pereiopod is rather stout, reaching the second segment of the antennular peduncle. The carpus of the second pereiopod is subdivided into seven joints. The third pereiopod reaches forward nearly as far as the lateral spine of the antennal scale; the merus is armed with three lateral spines; there are five (right) and six (left) spinules on the ventral side of the dactylus excluding the terminal claw which is long, about half length of 
the remaining part of the dactylus. The fourth pereiopod is missing in both sides. The fifth pereiopod is as in the third pereioped.
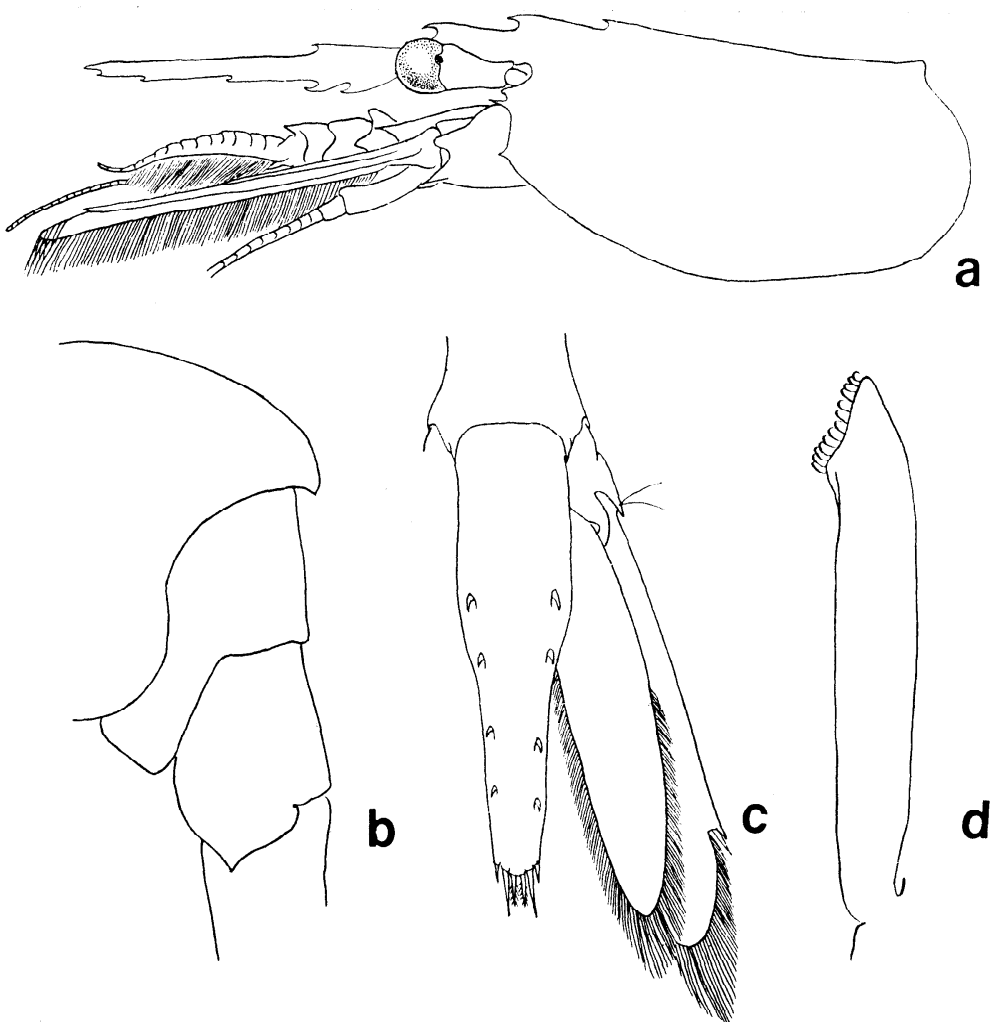

Fig. 3. Eualus kuratai sp. nov.

a, Anterior part of body of holotype, $\times 7.5$; b, third to sixth abdominal somites of paratype, $\times 7.5$; c, telson and right uropod of holotype, $\times 10.5$; $\mathrm{d}$, appendix interna of paratypc.

The ending of the third abdominal somite is obtuscly pointed, but both fourth and fifth somites are entirely smooth, without the posteromedian spine; the pleuron of the fifth somite is pointed posteriorly (Fig. $3, \mathrm{~b}$ ). The telson is as long as the sixth somite and armed with four pairs of spines; there are one pair of plumose hairs and two pairs of terminal spines, the inner pair is the longest. The endopod of the uropod is as long as or slightly shorter than the telson including the terminal spines (Fig. 3, c).

Description of paratypes: The paratypes are agree well with the holotype in their main characters, but their pereiopods are almost missing. And moreover, two specimens are broken out in their rostrum, the rest intact specimen has four teeth on the upper border and six teeth on 
the lower border. The mandibular palp is composed of two joints, and the incisor process has six teeth. The appendix interna is long, six times as long as broad and bears minute coupling hooks on the distal onefourth of the inner margin (Fig. 3, d).

Remarks: This species is very closely related to $E$. middendorffi, especially the young specimens of the latter in many respects, but the differences between the two species will be mentioned below.

In E. middendorffi each of the fourth and fifth abdominal somites is provided with the posteromedian spine that is entirely absent in this new species. The ovigerous females of this species vary from 29 to 30 $\mathrm{mm}$ in body length, and much shorter than that of $E$. middendorffi measuring 41 and $65 \mathrm{~mm}$.

This species is named in honour of Dr. H. Kurata who offered us the specimens.

Eualus gracilirostris (Stimpson, 1860)

(Fig. 4, a-c)

Hippolyte gracilirostris Stimpson, 1860, 103-Hakodadi [Hakodate], Hokkaido, (Type locality).

Spirontocaris gracilirostris: Balss, 1914, 44, fig. 25-Sagami Bay, $150 \mathrm{~m}$; Todokokke, Hokkaido; Fukuura, Sagami Bay.

Spirontocaris gracilirostris: Yokoya, 1933, 26-North of Oga, Sea of Japan, $145 \mathrm{~m}$.

Spirontocaris gracilirostris: Urita, 1942, 27, fig. 7-Aniwa Bay, Southern Sakhalin, 0-20 m.

Eualus gracilirostris: Holthuis, 1947, 11-No locality.

Material examined:

Aburatsubo, Kanagawa Pref., 7 尔令, 4 ovig. 우우, ZLKU No. 1112, Apr. 18, 1957, O. Tabeta leg.

Aio-Bay, Yamaguchi Pref., Tidal zone, 3 ovig. 우우, ZLKU No. 8163, June 17, 1966, K. I. Hayashi leg.

Munakata-oshima Is., Fukuoka Pref., 1 ovig. 우, ZLKU No. 1134, Apr. 1957, Y. Motomatsu leg.

Munakata-oshima Is., Fukuoka Pref., 1 ovig. 우, ZLKU No. 1977, Feb. 9, 1959, Y. Motomatsu leg.

Munakata-oshima Is., Fukuoka Pref., 2 ovig. 우우, ZLKU No. 8067, Mar. 29, 1963, collector unknown.

Tsuyazaki, Fukuoka Pref., 1 ovig. 우, ZLKU No. 1098, Mar. 18, 1957, collector unknown.

Mitoma, Fukuoka Pref., Sea shore, 1 ovig. 우, ZLKU No. 1146, Apr. 29, 1957, K. Ueki leg.

Shikano-shima Is., Fukuoka Pref., Tide pool, 10 ovig. 우우 ZLKU No. 8079, May 2, 1965, K. I. Hayashi leg. 
Shikano-shima Is., Fukuoka Pref., Tide pool, 6 ovig. 우우, 18 juv., ZLKU No. 8089, May 31, 1965, K. I. Hayashi leg.

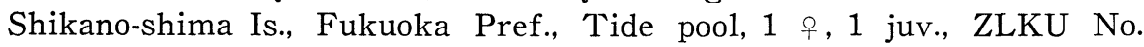
8161, July 17, 1966, K. Baba leg.

Fukae, Nagasaki Pref., Sea shore, 1 ovig. 우, 1 우, ZLKU No. 304, May 22, 1954, T. Senta leg.

Tsuji-shima Is., Amakusa Is., Kumamoto Pref., Rocky shore, 1 ovig. 우, ZLKU No. 8069, Apr. 25, 1963, T. Kikuchi leg.

Description: The species differs in external features in both sexes, the ovigerous females vary from 17 to $22 \mathrm{~mm}$ and the males are about $14 \mathrm{~mm}$ in body length. The rostrum is slender and provided with six teeth on the upper border, of which the posterior one is situated on the carapace, and with two to four teeth (mostly two in male, three in female) on the lower border near the apex; the apex of the rostrum extends to

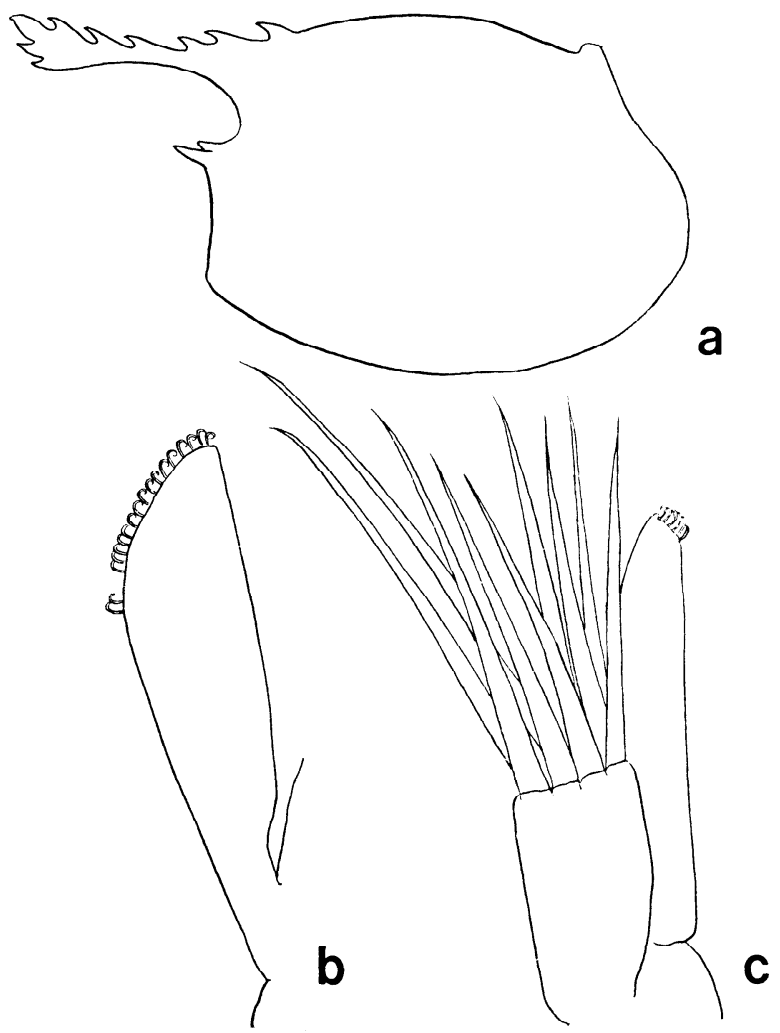

Fig. 4. Eualus gracilirostris (Stimpson).

a, Carapace and rostrum ; b, appendix interna in female ; c, appendix interna and appendix masculina in male. 
the distal articulation of the third segment of the antennular peduncle in female, whereas it extends the distal tip of the eye and does not reach the distal tip of the second segment in male. The carapace is longer than the rostrum and provided with only the antennal spine in most specimens (Fig. 4, a), but three females have a spine on the pterygostomian angle; one from Abratsubo, Kanagawa Pref. has a tiny spine on the left side, but is destitute of it on the right side, the other two from Fukae, Nagasaki Pref. and Amakusa Is., Kumamoto Pref. have a small but conspicuous spine on either side of the pterygostomian angle.

The eye is moderate, the stalk is rather longer than the cornea.

The antennular peduncle reaches the half point of the antennal scale; the three segments of the antennular peduncle are provided with a small spine on the dorsal side of the anterior margin of each segment; the stylocerite of the female specimen reaches the middle point of the second segment of the antennal peduncle, but that of the male is rather shorter reaching almost to the distal margin of the first segment of the antennular peduncle. The antennal scale is broad, about half as long as broad.

The third maxilliped exceeds the antennal scale by one-fourth length of the ultimate segment in female but reaches the tip of the antennal scale in male, and provided with both of the exopod and epipod. The first pereiopod is short and robust, extending to the distal extremity of the antennular peduncle in both sexes, and provided with the epipod. The second pereiopod is slender and provided with the epipod; the carpus is subdivided into seven joints, the proportional length of each joint is equal to that of the former two species. The following three pereiopods are subequal in features and without epipod; the merus of the third pereiopod is armed with two to five (mostly four) spines on the lateral side at the distal half; the dactylus of the third pereiopod is armed with five or six spinules in female and seven or eight in male, excluding the terminal claw on the ventral side.

The endings of all the abdominal somites are smooth and the pleura of the fourth and fifth somites are posteriorly pointed; the telson is about one and a half times as long as the sixth somite and provided with four pairs of spines on the dorsal side. The apex of the telson is acutely pointed with two pairs of spines and one or two pairs of hairs.

The appendix interna of the female is rather expanded in the distal part bearing many coupling hooks (Fig. 4, b), and the appendix masculina of the male is large and short, being half the length of the appendix interna of the male with truncated tip bearing nine long hairs (Fig. 4, c).

Colour; The ground colour of this species is pale brown or yellowishgreen. The carapace is ornamented with some (mostly five) transverse 
line of red brown colour. On the abdominal somites there are one transverse line of same colour on the first somite and two similar lines on both second and third somites. The tail fan has a broad transverse band of dark brown. The antennal flagellum is light orange. The third maxilliped and following five pereiopods have some greenish-brown bands. The eggs are dull green.

Remarks: The species was originally described by Stimpson(1860) from Hakodadi [Hakodate, Hokkaido] and subsequently recorded from northward into Saghalien to southward into Sagami Bay. Our material is collected from several localities of southern Japan, from Kanagawa Pref. to Kumamoto Pref. This species, therefore, is distributed all over the seas around Japan and usually collected together with some palaemonoid shrimps, Palaemon (Palaemon) serrifer (Stimpson) in tidal zone of rocky shore.

The specimens, especially male at hand, agree with the description of the type given by Stimpson (1860), except for the presence of the pterygostomian spine, and also agree well with the descriptions and illustrations by Balss (1914) and Urita (1942), that show no pterygostomian spine. The species is divided roughly into two forms by the presence or absence of the pterygostomian spine. The type specimen has such a spine but the specimens examined are not provided with this spine, except for only three ovigerous fcmale. Of these spine-presentforms, one from Aburatsubo, Kanagawa Pref. has a spine on the left side only, and were collected together with the spine-absent-form at the same time and same locality.

Although it may be uncommon that the presence or absence of the pterygostomian spine occurs under infraspecific level, these two forms seem to be identical each other from the following two points:1) There are no morphological differences between two forms except for the pterygostomian spine, and 2) the asymmetrical growth of the pterygostomian spines is observed, and two forms occur at the same time and same locality. This species, however, is usually the absent-form, and rarely mixed with the present-form in the natural popuration.

Eualus leptognathus (Stimpson, 1860)

(Fig. 5, a-c)

Hippolyte leptognatha Stimpson, 1860, 103-Hakodadi [Hakodate], Hokkaido, (Type locality).

non Hippolyte leptognatha: Miers, 1879, 56-Tokyo Bay.

Spirontocaris japonica Yokoya, 1930, 533, fig. 3-Mutsu Bay, ca. 10 m, among sca-wccds.

Spirontocaris leptognatha: Yokoya, 1933, 26-Siriya-zaki, Aomori Pref., 594 
$\mathrm{m}$; Todo-saki, Iwate Pref., $644 \mathrm{~m}$.

Spirontocaris japonica: Yokoya, 1930, 271, fig. 6-Onagawa, Miyagi Pref., 0-10 m.

Eualus leptognathus: Holthuis, 1947, 11,43- No locality.

Eualus leptognathus: Sando, 1964, 32 - Aomori Bay, very common in Zostera belt.

Material examined:

Notsuke Bay, Hokkaido faced to the Sea of Okhotsk, $5 \mathrm{~m}$ deep, 4 ovig. P우, ZLKU No. 2426, June 17, 1962, H. Kurata leg.

Tomioka, Amakusa Is., Dredge, 1 ovig. 우, ZLKU No. 1201, Apr. 1, 1958, T. Habe leg.

Tomioka Bay, Amakusa Is., Zostera belt, Dredge, 1 ovig. 9, ZLKU No. 3674, Apr. 2, 1958, T. Kikuchi leg.

Tomioka Bay, Amakusa Is., Zostera belt, Collected by a small Danish seine, 18 juv., ZLKU No. 3675, Aug. 2, 1958, T. Kikuchi leg.

Tomioka Bay, Amakusa Is., Zostera belt, Coll. by a small Danish seine 1 s. ZLKU No. 4056, Nov. 27, 1958, T. Kikuchi leg.

Tomioka Bay, Amakusa Is., Zostera belt, Coll. by a small Danish seine 1 ई , ZLKU No. 4057, Dec. 23, 1958, T. Kikuchi leg.

Tomioka Bay, Amakusa Is., Zostera belt, Coll. by a small Danish seine 1 s, ZLKU No. 8173, Jan. 9, 1959, T. Kicuchi leg.

Tomioka Bay, Amakusa Is., Zostera belt, Coll. by a small Danish seine 21 juv., ZLKU No. 5145, Apr. 24, 1959, T. Kikuchi leg.

Tomioka Bay, Amakusa Is., Zostera belt, Coll. by a small Danish seine 11 juv., ZLKU No. 5640, May 21, 1959, T. Kikuchi leg.

Tomioka Bay, Amakusa Is., Zostera belt, Coll. by a small Danish seine 113 juv., ZLKU No. 5753, June 21, 1959, T. Kikuchi leg.

Tomioka Bay, Amakusa Is., Zostera belt, Coll. by a small Danish seine 25 juv., ZLKU No. 6238, July 19, 1959, T. Kikuchi leg.

Tomioka Bay, Amakusa Is., Zostera belt, Coll. by a small Danish seine 1 juv., ZLKU No. 7051, Aug. 2, 1959, T. Kikuchi leg.

Tomioka Bay, Amakusa Is., Zostera belt, Coll. by a small Danish seine 80 juv., ZLKU No. 7161, Aug. 19, 1959, T. Kikuchi leg.

Tomioka Bay, Amakusa Is., Zostera belt, Coll. by a small Danish seine 4 juv., ZLKU No. 8063, Sept. 15, 1959, T. Kikuchi leg.

Description: The species is about $25 \mathrm{~mm}$ in body length. The rostrum is large, laterally compressed, apically upward, and longer than the carapace: the upper border of the rostrum is provided with three to six teeth on the proximal half, and the distal half of the lower border is provided with two to five (mostly three) teeth on the distal half in front of the foremost tooth on the upper border. The antennal spine is acutely pointed, setting below the obtuse suborbital angle and the pterygostomian spine is small but distinct (Fig. 5, a). 
The eye is rather large, and the stalk is longer than the cornea.

The thicker antennular flagellum extends to the rostral apex; the stylocerite is broad, reaching the distal tip of the basal segment of the antennular peduncle, the three segments of the antennular peduncle cach is provided with a small spine at the anterior part of the dorsal side. The antennal scale is large, measuring about five times as long as broad, and exceeds scarcely beyond the apex of the rostrum; the outer margin is straight and ends in a strong spine falling short of the lamellar part of the scale.

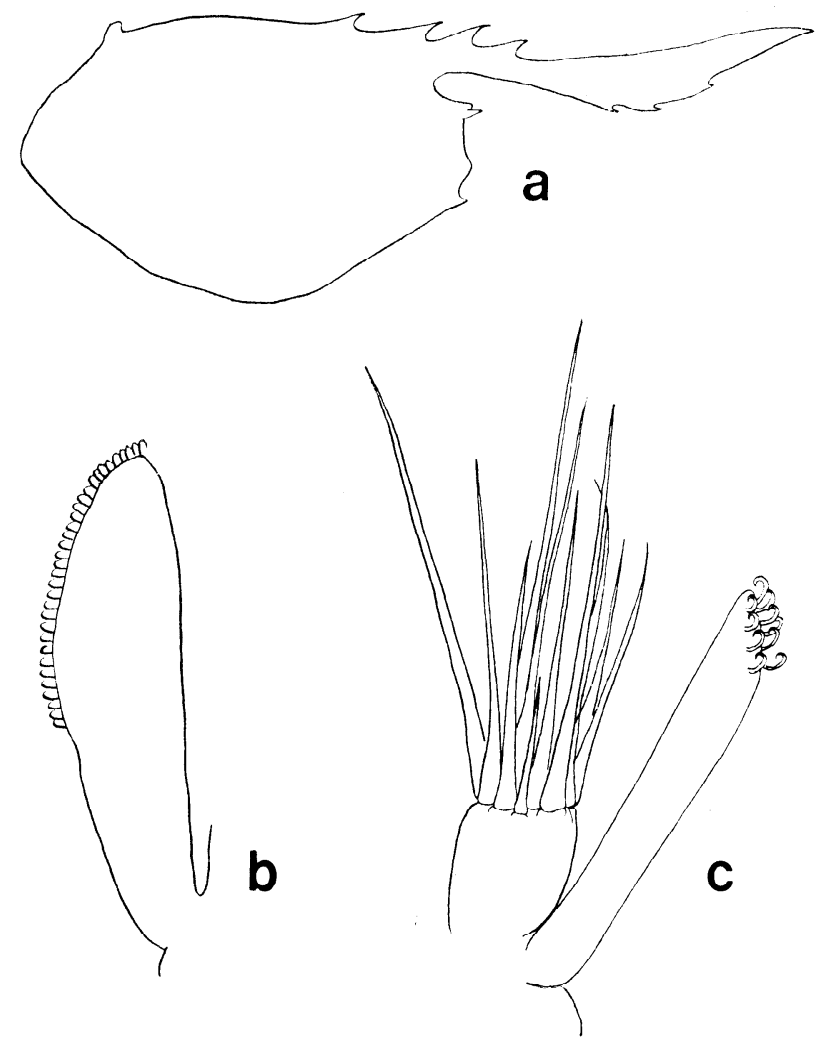

Fig. 5. Eualus leptognathus (Stimpson).

a, Carapace and rostrum ; b, appendix interna in female ; c, appendix interna and appendix masculina in male.

The third maxilliped, which extends to the distal tip of the antennal scale, is provided with both of the epipod and exopod. The anterior three pereiopods are also provided with the epipods. The first pereiopod is rather stout and short, extending to the anterior tip of the antennular 
peduncle. The second pereiopod is slender and long, extending to or slightly over the antennal scale. The third pereiopod reaches scarcely to the tip of the antennal scale, the merus is armed with four to seven lateral spines; the dactylus is also armed with one stout and six or seven slender spinules excluding the terminal claw on the ventral margin. The fourth pereiopod extends forward to the end of the antennular peduncle; the merus is armed with four to five lateral spines. The fifth pereiopod reaches nearly as far as the tip of the stylocerite; the merus is armed with three or four spines.

The third abdominal somite is large and produced in low bleunt process over the anterior part of the fourth somite. The pleuron of the fourth somite is unarmed posteriorly but that of the fifth is pointed acutely. The telson is about one and a third times as long as the sixth somite, with four or five pairs of dorsal spines. The apex of the telson is acutely pointed with two pairs of spines and one pair of plumose hairs.

The appendix interna in female is rather large, expanding toward the apex which bears many coupling hooks along the distal half of the inner margin (Fig. 5, b). The male specimens are smaller and slenderer than the females; the appendices of the male are very closely related to that of $E$. gracilirostris in general form; the appendix masculina bears 11 long hairs on the truncated apex (Fig. 5, c).

Remarks: The material including the juvenile specimens agrees well with the original description by Stimpson (1860) except for fewer number of teeth situated on the carapace, but the rostral teeth counted by Miers (1879), especially on the lower border, are too numerous to be identical with this species.

Judging from the description of Spirontocaris japonica (Yokoya, 1930 \& 1939), it is a synonym of Eualus leptognatus (Stimpson), as already pointed by Holthuis (1947).

This species has often been recorded only from the northern Japan as E. gracilirostris. In the Zostera belt of Tomioka Bay many juvenile specimens of the present species are usually collected from April to September, particularly abundant in June to August, but the adult are very scarce in all the year. The Zostera belt may be a more suitable place for the juvenile specimens of this species.

Eualus kikuchii sp. nov.

(Figs. 6 and 7, a-d)

Holotype: Tomioka Bay, Amakusa Is., 1 s, ZLKU No. 8076, Apr. 21, 1964, T. Kikuchi leg.

Paratypes: Off Uze, Amakusa Is., 3 ovig. 우우, 1 우, ZLKU No. 8072, Apr. 14, 1964, T. Kikuchi leg. 
Data as for the holotype, 1 of, ZLKU No. 8077.

Description of holotype: The specimen is very small, measuring only $11 \mathrm{~mm}$ in total length from the apex of the rostrum to the tip of the telson (Fig. 6). The rostrum is short and apically downward, not extending to the distal extremity of the eye; the upper border of the rostrum is armed with five teeth arranged equidistantly, of which the hindmost one is the smallest and rather scparated from the rostral apex; the lower border is armed with only one tooth near the apex in front of the foremost one on the upper border. The carapace is about two times as long as the rostrum; the lower limit of the orbit is rounded and continuous with the antennal spine without the notch; the pterygostomian spine is small but conspicuous (Fig. 7, a).

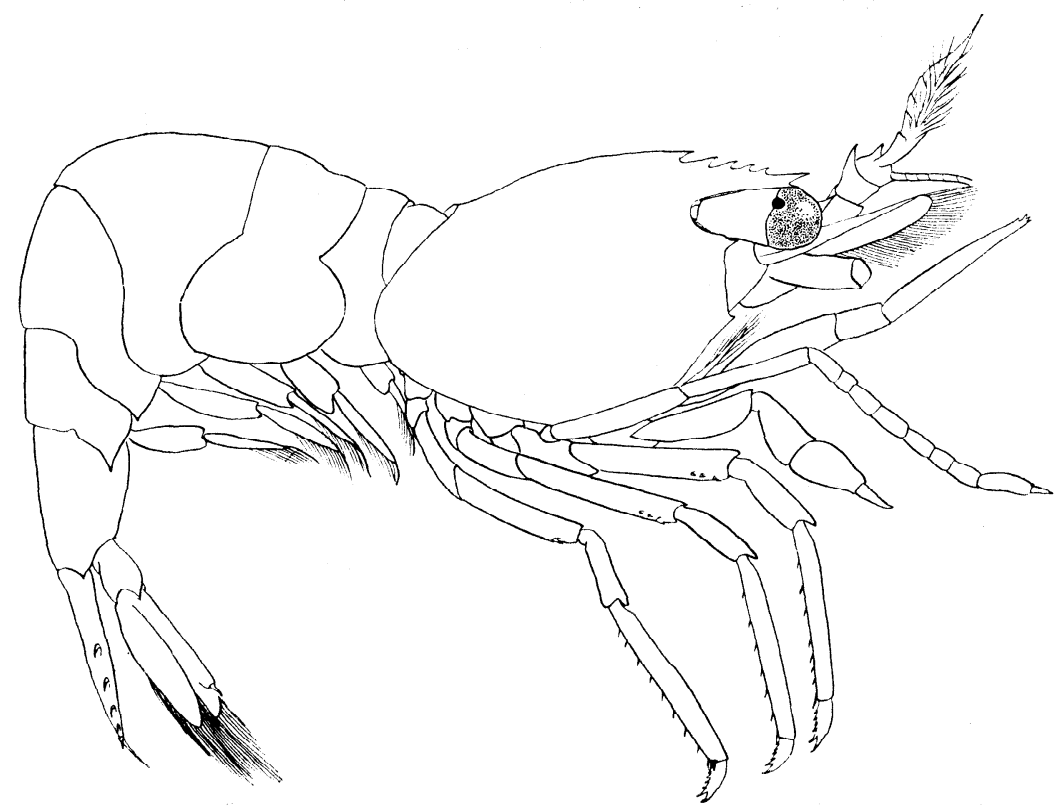

Fig. 6. Eualus kikuchii sp. nov., paratype, 10.

The eye is large; the stalk is rather longer than the cornea.

There is a large spine on the anterior margin of the basal segment of the antennular peduncle; the second and third peduncular segments are short, and also provided with an acute spine (Fig. 7, b). The outer margin of the antennal scale is straight, terminating in a stout spine which extends as far as the end of the lamellar portion. 
The third maxilliped reaches beyond the tip of the antennal scale; the ultimate segment of the maxilliped is about three times as long as penultimate segment and armed with four bristles near the apex. The exopod is present, being shorter than the antepenultimate segment, and also the small epipod is present.

The first pereiopod extends to the half point of the antennal scale. The second pereiopod is slenderer than the first pereiopod, and just exceeds the tip of the third maxilliped; the carpus is subdivided into seven joints. The following three pereiopods are subequal in shape; there are three spines on each merus of the third and fourth pereiopods, and one spine on the fifth pereiopod; the dactylus of these three pereiopods are armed with four or five stout spines excluding the terminal claw.
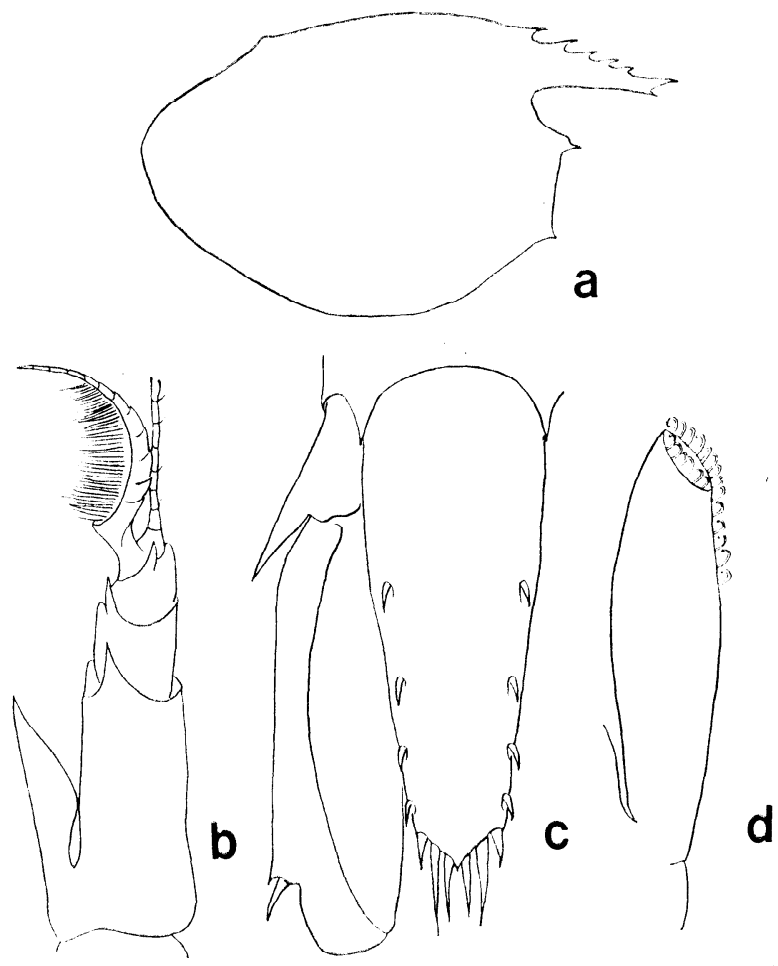

Fig. 7. Eualus kikuchii sp. nov., paratype.

a, Carapace and rostrum; b, antennular peduncle; c, telson and left uropod; d, appendix interna in female.

The pleura of the fourth and fifth abdominal somites are pointed posteriorly. The sixth somite is rather shorter than the telson which is nearly as long as the uropod. There are four pairs of the dorsal 
spines on the distal three-fourths, and also two pairs of the terminal spines and one pair of hairs on the apex of the telson which is triangular in shape (Fig. 7, c).

Description of paratypes: The paratypes are all female specimens including the allotype, measuring $10.1-15.1 \mathrm{~mm}$ in total length, and coincide with the holotypc in all the respects. The upper border of the rostrum is armed with five (four specimens) or six (one specimen) teeth, and the lower border of the rostrum is armed with one (three specimens) or no (two specimens) teeth near the apex.

The mandible is composed of a two-jointed palp, a rather large incisor process with four teeth and a stout molar process.

The appendix interna in female situating on the middle of the endopod of the second pleopod bears many coupling hooks on the distal third of the inner margin (Fig. 7, d).

Remarks: The present new species can be easily distinguished from the other species of this genus by its smaller size and the shape of the anterior part of the body, and is related to Spirontocaris sinensis described by $\mathrm{Yu}$ (1931) from Chefoo [Yentai], although the latter is an unsettled species for which nothing is known about the exopod of the third maxilliped. These two species, however, are easily distingushed by the following characters. 1) This new species is provided with only one or no tooth on the lower border of the rostrum which reaches to the distal tip of the first antennular peduncle, whereas Spirontocaris sinensis has two small teeth on the lower border of the rostrum which reaches to the distal extremity of the second segment of the antennular peduncle, and 2) the pterygostomian angle is pointed, developed with the spine in this species instead of being absent in Spirontocaris sinensis.

This species is named in honour of Dr. T. Kikuchi who collected the specimens.

\section{References}

Balss, H., 1914. Ostasiatische Decapoden II. Die Natantia und Reptantia. In: Doflein, F., Beiträge zur Naturgeschichte Ostasiens. Abh. math.-phys. K1. K. Bayer. Akad. Wiss., suppl. vol. 2, pt. 10, pp. 1-101, figs. 1-50, pl. 1.

Brashinikov, V., 1907. Matériaux pour servie à la connaissance de la faune des mers russes de l'est rassemblés par le shooner "Storoz" en 1899-1902. Mém. Acad. Sci. Petersb., ser. 8, vol. 20, pt. 6, pp. 1-185, figs. 1-26, pls. 1, 2, 1 map (not read).

Derjugin, K. M. and S. Kobjakowa, 1935. Zur Dekapodenfauna des Japanische Mecres. Zool. Anz., vol. 112, pp. 141-147, fig. 1.

Holthuis, L. B., 1947. The Decapoda of the Siboga Expedition. Part IX. The Hippolytidae and Rhynchocinetidae collected by the Siboga and Snellius Expeditions, with remarks on other species. Siboga Exped., Livr. 140, Mon. XXXIX a8, pp. 1-100, 
figs. 1-15.

Miers, E. J., 1879. On a collection of Crustacea made by Capt. H. C. St. John R. N., in the Corean and Japanese Seas. Part I. Podophthalmia. Proc. zool. Soc. Lond., 1879, pp. 18-61, pls. 1-3.

Miyake, S., Sakai, K. and S. Nishikawa, 1962. A fauna-list of the decapod Crustacea from the coasts washed by the Tsushima Warm Current. Rec. Oceanogr. Wks. Japan, Sp. no. 6, pp. 121-131.

Rathbun, M. J., 1902. Descriptions of new decapod crustaceans from the west coast of North America. Proc. U. S. Nat. Mus., vol. 24, pp. 885-905.

- 1904. Decapod crustaceans of the northwest coast of North America. Harriman Alaska Exped., vol. 10, pp. 1-190. figs. 1-95, pls. 1-10.

Sando, H., 1964. Faunal list of the Zostera marina region at Kugurizaka coastal waters, Aomori Bay. Bull. Mar. Biol. Stat. Asamushi, Japan, vol. 12, pp. 27-35.

Stimpson, W., 1860. Prodromus descriptionis animalium evertebratorum, quac in Expeditione ad Oceanum Pacificum Septentrionalem, a Republica Federata missa, C. Ringgold et J. Rodgers Ducibus, observavit et descripsit. Proc. Acad. nat. Sci. Philad., 1860, pp. 22-48 (91-117).

Thallwitz, J., 1892. Decapoden-Studien, insbesondere basirt auf A. B. Meyer's Sammlungen im Ostindischen Archipel, nebst einer Aufzählung der Decapoden und Stomatopoden des Dresdener Museums. Abh. Ber. zool.-anthrop. Mus. Dresden, 1890-91, pt. 3, pp. 1-55, p1. 1.

Urita, T., 1942. Decapod crustaceans from Saghalien, Japan. Bull. Biogeograph. Soc. Japan, vol. 12, pp. 1-78, figs. 1-16.

Yokoya, Y., 1930. Report of the biological survey of Mutsu Bay. No. 16. Macrura of Mutsu Bay. Sci. Rep. Tôhoku Imp. Univ., ser. 4, vol. 5, pp. 525-548, figs. 1-5, pl. 16.

1933. On the distribution of decapod crustaceans inhabiting the continental shelf around Japan, chiefly based upon the materials collected by S. S. SoyoMaru, during the year 1923-1930. J. Coll. Agric. Tokyo Imp. Univ., vol. 12, pp. 1-226, figs. 171.

, 1939. Macrura and Anomura of decapod Crustacea found in the neighbourhood of Onagawa, Miyagi-Ken. Sci. Rep. Tôhoku Imp. Univ., ser. 4, vol. 14, pp. 261-289, figs. 1-13.

Yu, S. C., 1931. Description de deux nouvelles crevettes de Chine. Bull. Mus. Hist. nat. Paris, ser. 2, vol. 3, pp. 513-516, figs. 1, 2. 